\title{
Correction to: Number processing outside awareness? Systematically testing sensitivities of direct and indirect measures of consciousness
}

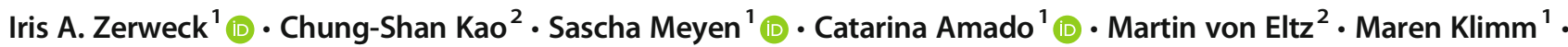 \\ Volker H. Franz ${ }^{1}$
}

(C) The Authors(s) 2022

\section{Correction to: Atten Percept Psychophys. https://doi.org/10.3758/s13414-021-02312-2}

The originally posted PDF version of the article contained minor copy-editing mistakes caused by the publisher when the HTML was converted to PDF. The corrected version is available since 28 June 2021.

Open Access This article is licensed under a Creative Commons Attribution 4.0 International License, which permits use, sharing, adaptation, distribution and reproduction in any medium or format, as long as you give appropriate credit to the original author(s) and the source, provide a link to the Creative Commons licence, and indicate if changes were made. The images or other third party material in this article are included in the article's Creative Commons licence, unless indicated otherwise in a credit line to the material. If material is not included in the article's Creative Commons licence and your intended use is not permitted by statutory regulation or exceeds the permitted use, you will need to obtain permission directly from the copyright holder. To view a copy of this licence, visit http://creativecommons.org/licenses/by/4.0/.

Publisher's note Springer Nature remains neutral with regard to jurisdictional claims in published maps and institutional affiliations.

The online version of the original article can be found at https://doi.org/ 10.3758/s13414-021-02312-2

Iris A. Zerweck

iris.zerweck@uni-tuebingen.de

1 Department of Computer Science, Experimental Cognitive Science, University of Tübingen, Sand 6, 72076 Tübingen, Germany

2 General Psychology, Universität Hamburg, Hamburg, Germany 